\title{
Flexibacter ovolyticus sp. nov., a Pathogen of Eggs and Larvae of Atlantic Halibut, Hippoglossus hippoglossus L.
}

\author{
GEIR HøVIK HANSEN, ${ }^{1} \dagger^{*} \emptyset$ IVIND BERGH,${ }^{2}$ JONE MICHAELSEN, ${ }^{1}$ AND DAG KNAPPSKOG ${ }^{3}$ \\ Department of Microbiology and Plant Physiology, University of Bergen, Jahnebakken 5, N-5007 Bergen, ${ }^{1}$ \\ Institute of Marine Research, Austevoll Aquaculture Research Station, N-5392 Storeb $\phi,{ }^{2}$ and \\ NORBIO $A / S, N-5008$ Bergen, ${ }^{3}$ Norway
}

\begin{abstract}
A psychrotrophic Flexibacter sp., Flexibacter ovolyticus sp. nov., was isolated from the adherent bacterial epiflora of Atlantic halibut (Hippoglossus hippoglossus L.) eggs and was shown to be an opportunistic pathogen for halibut eggs and larvae. The strains which we isolated had the enzymatic capacity to dissolve both the chorion and the zona radiata of the egg shells. A total of 35 isolates were characterized by using morphological and biochemical tests. These strains were rod shaped, gram negative, Kovacs oxidase positive, and pale yellow and exhibited gliding motility. They did not produce acid from any of the wide range of carbohydrates tested. Our isolates had the ability to degrade gelatin, tyrosine, DNA, and Tween 80 . Starch, cellulose, and chitin were not degraded. The strains were catalase and nitrate reductase positive, did not produce $\mathrm{H}_{2} \mathrm{~S}$, and did not grow under anaerobic conditions. $F$. ovolyticus resembles Flexibacter maritimus, but differs from the latter species in several biochemical and physiological characteristics. DNAs from $F$. ovolyticus strains had guanine-pluscytosine contents which ranged from 30.3 to 32.0 mol\% (strains EKC001, EKD002 ${ }^{\mathrm{T}}$ [ $\mathrm{T}=$ type strain], and VKB004), and DNA-DNA hybridization studies revealed levels of relatedness between $F$. ovolyticus EKD002 and $F$. maritimus NCMB $2154^{\mathrm{T}}$ and NCMB 2153 of 42.7 and $30.0 \%$, respectively. Compared with previously described Cytophaga and Flexibacter spp. with low guanine-plus-cytosine contents, $F$. ovolyticus constitutes a new species. Strain EKD002 (= NCIMB 13127) is the type strain of the new species.
\end{abstract}

Fish-pathogenic bacteria belonging to the order Cytophagales are well-known agents of disease in both freshwater and seawater fish species $(23,27,34,35)$, often causing high levels of mortality and economic losses in aquaculture operations. Increased interest in bringing new fish species into aquaculture has resulted in the expenditure of great effort to mass produce marine fish larvae, and Atlantic halibut (Hippoglossus hippoglossus L.) has been one of the most promising candidates for cold-water aquaculture (45). However, commercial success has been hampered by substantial mortality in the early stages of life $(37,38)$.

The existence of bacteria that colonize the surfaces of marine fish eggs has been recognized for a long time $(36,43)$. The mucosal surfaces of marine fish eggs are a good substrate for the adhesion and colonization of bacteria (21), and many of these colonizing bacteria are opportunistic in nature. Such colonization eventually results in disease and increased levels of mortality when various environmental stresses cause suboptimal conditions for eggs and larvae. Recently, bacteria belonging to the genus Flexibacter have been shown to play an important role in this process $(4,5)$. Egg groups in which Flexibacter sp. was present as a major component of the adherent egg epiflora exhibited very high levels of mortality on the days around hatching compared with egg groups in which Flexibacter sp. could not be detected or was present only as a minor part of the epiflora. Experimental infection trials in which Flexibacter sp. and Vibrio spp. were incubated with individual halibut eggs and larvae revealed that the pathogenesis and mortality patterns obtained with these taxa were quite different (5). Flexibacter sp. caused very high levels of mortality on the last few days before hatching and during the first few days after hatching.

\footnotetext{
* Corresponding author.

$\dagger$ Present address: The Norwegian School of Safety Engineering and Management, Skåregt. 103, N-5500 Haugesund, Norway.
}

In contrast, various Vibrio spp. did not cause mortality at the egg stage, but did cause increasing levels of mortality throughout the yolk sac stage.

The nomenclature of the nonphotosynthetic, nonfruiting, gliding bacteria has been somewhat confused $(40,41,44)$. Gliding bacteria isolated from diseased fish belong to the order Cytophagales and to either the genus Flexibacter or the genus Cytophaga (9). Problems concerning differentiation between the genera Cytophaga and Flexibacter and the taxonomic relationship of these taxa to the genus Flavobacterium have been recognized $(24,26,28,41)$, as indicated by references to the "Flavobacterium-Cytophaga group" by several authors. The names Flexibacter columnaris, Flexibacter psychrophilus (9), and Flexibacter maritimus (48) are validly published names for fish-pathogenic species belonging to the order Cytophagales.

In this study we characterized and described a new Flexibacter sp. that causes disease and high levels of mortality in the egg and larval stages of Atlantic halibut.

\section{MATERIALS AND METHODS}

Bacterial strains. A number of phenotypically similar Flexibacter-like bacterial strains (designated Flexibacter sp. below) were isolated from the adherent epiflora of halibut eggs obtained from different egg batches (strains EKC001 to EKC015 [5 April 1989] and strains EKD001 to EKD005 [27 April 1989]) and from the water in egg incubators (strains VKB001 to VKB015 [5 April 1989]). On the basis of the characteristic colony morphology and key differential characteristics (Tables 1 through 3), Flexibacter sp. strains were isolated from various egg groups in two consecutive hatching seasons (1990 and 1991). Eggs were washed five times in autoclaved $70 \%$ seawater, homogenized, and plated onto Difco marine agar (MBA) and cytophaga agar (2) based on $70 \%$ seawater (CYTA). A total of 30 isolates obtained from the egg epiflora and 5 water isolates were subjected to 
TABLE 1. Biochemical and physiological characteristics of $F$. ovolyticus and $F$. maritimus $\mathrm{NCMB} 2154^{\mathrm{T}}$

\begin{tabular}{|c|c|c|}
\hline Characteristic & $\begin{array}{l}\text { F. ovolyticus } \\
(n=35)^{a}\end{array}$ & $\begin{array}{l}\text { F. maritimus } \\
\text { NCMB } \\
2154^{\mathrm{T}}\end{array}$ \\
\hline \multicolumn{3}{|l|}{ Degradation of: } \\
\hline Agar & - & - \\
\hline Carboxymethyl cellulose & - & - \\
\hline Cellulose & - & - \\
\hline Chitin & - & - \\
\hline DNA & + & + \\
\hline Gelatin & + & + \\
\hline Starch & - & - \\
\hline Tween 80 & + & + \\
\hline Tyrosine & + & + \\
\hline Urea & - & - \\
\hline \multicolumn{3}{|l|}{ Nitrogen sources } \\
\hline Tryptone & + & + \\
\hline Casamino Acids & + & + \\
\hline Yeast extract & + & + \\
\hline Sodium glutamate & + & - \\
\hline Potassium nitrate & - & - \\
\hline \multicolumn{3}{|l|}{ Production of: } \\
\hline$\beta$-Galactosidase & - & - \\
\hline Catalase & + & + \\
\hline Nitrate reductase & + & + \\
\hline Ammonia & - & + \\
\hline Hydrogen sulfide & - & - \\
\hline Pigment on tyrosine & + & + \\
\hline Growth in tryptic soy broth & - & - \\
\hline Congo red adsorption & - & + \\
\hline Production of EHVP in liquid culture $b$ & - & + \\
\hline Growth in pellicle in liquid culture & - & + \\
\hline $\begin{array}{l}\text { Stimulation or inhibition of growth by } \\
\text { halibut egg homogenate }\end{array}$ & - & - \\
\hline $\mathrm{G}+\mathrm{C}$ content $(\mathrm{mol} \%)^{c}$ & 31.0 & 30.1 \\
\hline
\end{tabular}

${ }^{a}$ The $F$. ovolyticus isolates were very homogeneous and responded identically in all of the tests.,$+ 100 \%$ of the isolates were positive;,$- 100 \%$ of the isolates were negative. $n$ is the number of strains tested.

${ }^{b}$ EHVP, extracellular high-viscosity polysaccharide.

$c$ The value given for $F$. ovolyticus is the mean of the results for three strains (strain EKC001, $30.8 \mathrm{~mol} \%$; strain $\mathrm{EKD} 002^{\mathrm{T}}, 30.3 \mathrm{~mol} \%$; strain VKB004, $32.0 \mathrm{~mol} \%$ ).

phenotypic characterization. Strains equivalent to $F$. maritimus NCMB $2154^{\mathrm{T}}(\mathrm{T}=$ type strain) and NCMB 2153 (National Collection of Marine Bacteria, Aberdeen, Scotland) were used as reference strains.

Morphology and growth. Cell morphology was determined by using phase-contrast microscopy of live specimens, scanning electron microscopy of infected halibut eggs, and transmission electron microscopy of cultured strains. Gliding motility was verified by using phase-contrast microscopy of hanging-drop preparations. Descriptions of pigmentation and colonial morphology were based on observations of MBA and CYTA cultures that were incubated at $15^{\circ} \mathrm{C}$ for 3 to 5 days. Microcyst formation was tested by using the method of Dworkin and Gibson (17). The production of flexirubin pigments was determined by using the $\mathrm{KOH}$ test described by Mudarris and Austin (35), and the production of an extracellular galactosamine glycan was examined by using Congo red adsorption (25). Anaerobic growth was tested by incubating MBA cultures under an $\mathrm{N}_{2}$ atmosphere. Production of high-viscosity extracellular polysaccharides was examined in Difco marine broth (MB) after incubation for 3 days at $20^{\circ} \mathrm{C}$. We also examined growth on thiosulfatecitrate-bile-sucrose agar and tryptic soy agar.

Physiological and biochemical characteristics. All of the tests were carried out at $15^{\circ} \mathrm{C}$ unless stated otherwise. When solid media were used, $1.5 \%$ Bacto Agar (Difco) was added prior to autoclaving. The agar was washed five times in distilled water, centrifuged, frozen as a wet paste with a water content of approximately $90 \%$, and kept at $-20^{\circ} \mathrm{C}$ until it was used.

Growth at different temperatures was examined by using $\mathrm{MB}$, and growth in the presence of different $\mathrm{NaCl}$ concentrations was assayed in MB (Difco formula) containing $\mathrm{K}$ salts substituted for $\mathrm{Na}$ salts. The impact of different seawater concentrations on growth was assayed in cytophaga broth containing appropriate seawater concentrations. We examined utilization of the following nitrogen sources in a medium that was based on artificial seawater: tryptone, Casamino Acids, yeast extract, sodium glutamate, and potassium nitrate. The medium was made by adding sterile filtered solutions of $2.0 \%$ sodium acetate, $20 \%$ glucose, and an $\mathrm{N}$ source (final concentrations, $0.02,0.1$, and $0.1 \%$ ) to $1,000 \mathrm{ml}$ of boiled, filtered, autoclaved artificial seawater (Ultramarin; Waterlife Ltd., Middlesex, England). We examined the possible inhibitory or stimulating effects of a homogenate of surface-disinfected (Buffodine; Evans Vanodine Ltd., Preston, England) (6) halibut eggs on the growth of Flexibacter sp. by adding 50- $\mu$ l portions of homogenate to 5-mm wells in MBA plates onto which the bacterial strains were spread.

Gram staining was performed as described by Buck (12), and Kovacs oxidase and catalase activities were tested by using standard procedures. The following tests were performed as described by Hansen and Sørheim (22): oxidativefermentative metabolism of glucose; aerobic acid production from fructose, sucrose, galactose, mannose, mannitol, glycerol, ribose, and $N$-acetylglucosamine; arginine dihydrolase; lysine decarboxylase; ornithine decarboxylase; gelatinase; amylase; chitinase; $\beta$-galactosidase; urease; DNase; lipase (Tween 80); Simmons citrate; indole; and nitrate reductase. In addition, the following characteristics were examined: pigment production on and degradation of tyrosine; hydrolysis of cellulose and carboxymethyl cellulose; degradation of agar; and $\mathrm{H}_{2} \mathrm{~S}$ and $\mathrm{NH}_{3}$ production (30). The $\mathrm{H}_{2} \mathrm{~S}$ test was modified by using $\mathrm{MB}$ as a base and supplementing it with $0.01 \%$ L-cysteine. $\mathrm{H}_{2} \mathrm{~S}$ was detected by using lead acetate paper.

TABLE 2. Growth of $F$. ovolyticus and $F$. maritimus under various environmental conditions

\begin{tabular}{lcc}
\hline \multicolumn{1}{c}{ Environmental variable } & $\begin{array}{c}\text { F. ovolyticus } \\
(n=35)^{a}\end{array}$ & $\begin{array}{c}F \text { maritimus } \\
\text { NCMB 2154 }\end{array}$ \\
\hline Growth at: & + & - \\
$4^{\circ} \mathrm{C}$ & + & + \\
$10^{\circ} \mathrm{C}$ & + & + \\
$25^{\circ} \mathrm{C}$ & - & + \\
$30^{\circ} \mathrm{C}$ & & - \\
Growth in ${ }^{b}$ : & - & + \\
$20 \%$ Seawater & - & + \\
$30 \%$ Seawater & + & - \\
$50 \%$ Seawater & & + \\
Growth in the presence of $:$ & - & + \\
$0.5 \% \mathrm{NaCl}$ & + & - \\
$1.0 \% \mathrm{NaCl}$ & + & + \\
$3.0 \% \mathrm{NaCl}$ & - & + \\
$6.0 \% \mathrm{NaCl}$ & &
\end{tabular}

${ }^{a} n$ is the number of strains tested.

${ }^{b}$ Seawater-based cytophaga broth.

${ }^{c}$ MB (Difco formula) contained the appropriate amounts of $\mathrm{NaCl}$. The remaining sodium salts were replaced by the corresponding potassium salts. 
TABLE 3. Some characteristics that differentiate $F$. ovolyticus from previously described Cytophaga and Flexibacter species that have low DNA G+C contents ${ }^{a}$

\begin{tabular}{|c|c|c|c|c|c|c|c|}
\hline Characteristic & $\begin{array}{l}\text { Cytophaga } \\
\text { lytica }\end{array}$ & $\begin{array}{c}\text { Cytophaga } \\
\text { saccharophila }\end{array}$ & $\begin{array}{l}\text { Cytophaga } \\
\text { aquatilis }\end{array}$ & $\begin{array}{l}F . \\
\text { columnaris }\end{array}$ & $\begin{array}{c}\text { F. } \\
\text { psychrophilus }\end{array}$ & $\begin{array}{l}F . \\
\text { maritimus }\end{array}$ & $\begin{array}{c}F . \\
\text { ovolyticus }\end{array}$ \\
\hline Length of cells $(\mu \mathrm{m})$ & $1.5-3.5$ & $2.5-6$ & $2-15$ & $2-12$ & $1.5-7.5$ & $2-5$ & $2-20$ \\
\hline Flexirubin pigment & - & + & + & + & + & - & - \\
\hline Congo red adsorption & - & $\mathrm{N}^{b}$ & - & + & - & + & - \\
\hline Kovacs oxidase & + & - & - & + & + & + & + \\
\hline Catalase & + & - & + & + & - & + & + \\
\hline $\mathrm{NO}_{3}{ }^{-}$used as $\mathrm{N}$ source & - & $\mathbf{N}$ & + & - & $\mathbf{N}$ & - & - \\
\hline $\begin{array}{l}\text { Acid produced from carbohy- } \\
\text { drates aerobically }\end{array}$ & $\mathbf{N}$ & $\mathbf{N}$ & + & - & - & - & - \\
\hline \multicolumn{8}{|l|}{ Degradation of: } \\
\hline Starch & + & + & + & - & - & - & - \\
\hline Carboxymethyl cellulose & + & + & + & - & - & - & - \\
\hline Agar & + & + & - & - & - & - & - \\
\hline Chitin & - & - & + & - & - & - & - \\
\hline Tyrosine & + & $\mathrm{N}$ & + & - & + & + & + \\
\hline DNase & $\mathbf{N}$ & $\mathbf{N}$ & + & $\mathbf{N}$ & $\mathbf{N}$ & + & + \\
\hline$\beta$-Galactosidase & + & $\mathrm{N}$ & + & - & - & - & - \\
\hline $\mathrm{NO}_{3}^{-}$reduced & - & + & + & + & - & + & + \\
\hline $\mathrm{NH}_{3}$ produced & + & + & + & + & + & + & - \\
\hline $\mathrm{H}_{2} \mathrm{~S}$ produced & + & + & - & + & - & - & - \\
\hline Highest $\mathrm{NaCl}$ concn tolerated (\%) & 6 & 2 & 2 & 0.5 & 0.8 & $>3$ & $>3$ \\
\hline Growth on seawater media & + & - & - & - & - & + & + \\
\hline Growth at $4^{\circ} \mathrm{C}$ & $\mathrm{N}$ & + & - & + & + & - & + \\
\hline Maximum temp $\left({ }^{\circ} \mathrm{C}\right)$ & $<40$ & $<37$ & 30 & 37 & $<25$ & $<37$ & $<30$ \\
\hline $\mathrm{G}+\mathrm{C}$ content $(\mathrm{mol} \%)$ & $33(32-34)^{c}$ & $32(32-36)$ & 32 or 34 & 30 & 32 & $31(31-32)$ & $30(30-32)$ \\
\hline Habitat & Marine & Freshwater & Freshwater & Freshwater & Freshwater & Marine & Marine \\
\hline
\end{tabular}

${ }^{a}$ Data for Cytophaga lytica, Cytophaga saccharophila, Cytophaga aquatilis, F. columnaris, F. psychrophilus, and $F$. maritimus from references 7 through 9 , 40 , and 48 and this study.

${ }^{b} \mathrm{~N}$, no information available.

${ }^{c} \mathrm{G}+\mathrm{C}$ content of the type strain and, in parentheses, range of $\mathrm{G}+\mathrm{C}$ contents for the species.

API ZYM (Analytab Products, Montalieu-Vercieu, France) tests were used to detect various constitutive enzymes in Flexibacter sp. strains EKC001, EKD002 ${ }^{\mathrm{T}}$, and VKB004 and $F$. maritimus NCMB $2154^{\mathrm{T}}$ and NCMB 2153. The preparations were incubated for $12 \mathrm{~h}$ at $20^{\circ} \mathrm{C}$ as described by Bernardet and Grimont (9).

Gel electrophoresis of bacterial proteins. Sodium dodecyl sulfate-polyacrylamide gel electrophoresis (29) was performed with Flexibacter sp. strains EKC001 and EKD002 ${ }^{\mathrm{T}}$ (isolated from egg epiflora), Flexibacter sp. strain VKB004 (isolated from water from one of the incubating units), and $F$. maritimus NCMB 2153 and NCMB $2154^{\mathrm{T}}$. The bacteria were grown for $48 \mathrm{~h}$ at $15^{\circ} \mathrm{C}$ in prefiltered $\mathrm{MB}$ until the early stationary phase of growth and then were inactivated by using formalin (final concentration, $0.5 \%$ [vol/vol]) and pelleted by centrifugation for $20 \mathrm{~min}$ at $6,198 \times g$ (Minifuge $\mathrm{T}$; Heraeus Crist, Osterode, Germany). The resulting pellet was washed twice in $0.9 \% \mathrm{NaCl}$ and suspended in $1 \mathrm{ml}$ of distilled water, and this preparation was stored as $200-\mu l$ aliquots at $-80^{\circ} \mathrm{C}$. The bacteria were diluted three times in 2-mercaptoethanol containing $2 \times$ sample buffer (29), heated for $5 \mathrm{~min}$ at $95^{\circ} \mathrm{C}$, and applied to $12 \%$ polyacrylamide gels. The gels were run by using a Bio-Rad gel $(16-\mathrm{cm})$ system according to the manufacturer's recommendations. Proteins were visualized by silver staining as described by Marshall and Latner (33).

DNA isolation and purification. DNAs from strains EKC001, EKD002 ${ }^{\mathrm{T}}$, VKB004, NCMB 2154 ${ }^{\mathrm{T}}$, and NCMB 2153 were isolated and purified. The bacteria were grown for $48 \mathrm{~h}$ at $20^{\circ} \mathrm{C}$ in prefiltered $\mathrm{MB}$, which yielded 2 to $3 \mathrm{~g}$ (wet weight) of cells in the late exponential phase of growth. The cells were harvested by centrifugation, washed in saline-
EDTA $(0.15 \mathrm{M} \mathrm{NaCl}$ and $0.1 \mathrm{M}$ EDTA), and frozen at $-80^{\circ} \mathrm{C}$. The cells were lysed, and the nucleic acids were extracted and purified by using the method of Marmur (32). The DNA was purified until the ratio of $A_{260}$ to $A_{230}$ and the ratio of $A_{260}$ to $A_{280}$ were between 1.8 and 2.1 and between 1.8 and 1.9 , respectively.

G + C contents of DNAs. Guanine-plus-cytosine $(G+C)$ contents were determined for Flexibacter sp. strains EKC001, EKD002 ${ }^{\mathrm{T}}$, and VKB004 and $F$. maritimus NCMB $2154^{\mathrm{T}}$ and NCMB 2153. The $\mathrm{G}+\mathrm{C}$ contents of DNAs were determined by thermal denaturation (15), using $0.5 \times$ standard saline citrate (SSC; $1 \times \mathrm{SSC}$ is $0.15 \mathrm{M} \mathrm{NaCl}$ plus 0.015 $\mathrm{M}$ sodium citrate) as the solvent and DNA concentrations corresponding to an initial $A_{260}$ of 0.7 , representing approximately $35 \mu \mathrm{g}$ of DNA per ml (31). A Shimadzu model UV-240 spectrophotometer equipped as described by Torsvik et al. (46) was used. $G+C$ contents were calculated as described by De Ley (15). DNA from Escherichia coli ATCC $11775(\mathrm{G}+\mathrm{C}$ content, $51.5 \mathrm{~mol} \%$ ) was used as a standard.

DNA-DNA hybridization. The genetic relationship between Flexibacter sp. strains EKC001, EKD002 ${ }^{\mathrm{T}}$, and VKB004 and $F$. maritimus NCMB $2154^{\mathrm{T}}$ and NCMB 2153 was determined on the basis of spectrophotometrically recorded initial renaturation rates of the DNA types and mixtures of DNAs $(16,19,49)$. The DNA was sheared in a French pressure cell at $20,000 \mathrm{lb} \mathrm{in}^{-2}$, giving DNA fragments with a mean molecular mass of 420,000 daltons $(19,46)$. DNA concentrations of $56 \mu \mathrm{g} / \mathrm{ml}\left(A_{260}, 1.2\right)$ were used in the reassociation experiments; this is well below the upper limit of $80 \mu \mathrm{g}$ of DNA per ml recommended by Gillis et al. (19). Reassociations were performed in $2 \times$ SSC. In the interval between $0.125 \times \mathrm{SSC}$ and $4 \times \mathrm{SSC}$, the DNA melting tem- 
perature $\left(T_{m}\right)$ and the optimal reassociation temperature $\left(T_{\text {OR }}\right)$ both increase by approximately $4^{\circ} \mathrm{C}$ as a result of a doubling of the $\mathrm{Na}^{+}$concentration (19). According to Gillis et al. (19), the $T_{\mathrm{OR}}$ at a given SSC concentration is 20 to $26^{\circ} \mathrm{C}$ below the $T_{m}$ at that SSC concentration. The velocity of reassociation is approximately independent of temperature from the $T_{\mathrm{OR}}$ to about $15^{\circ} \mathrm{C}$ below the $T_{\mathrm{OR}}(19)$. The $T_{\mathrm{OR}}$ was calculated by using the $T_{m}$ in $2 \times \mathrm{SSC}$, which was calculated from the $T_{m}$ in $0.5 \times \mathrm{SSC}$ as described by De Ley (15). This led to $T_{m}$ values (in $2 \times \mathrm{SSC}$ ) of $94.5^{\circ} \mathrm{C}$ for $E$. coli and about $86^{\circ} \mathrm{C}$ for the Flexibacter sp. and $F$. maritimus strains. The reassociation experiments were performed by using a $T_{\mathrm{OR}}$ of $60^{\circ} \mathrm{C}$ for the two Flexibacter species and a $T_{\mathrm{OR}}$ of $70^{\circ} \mathrm{C}$ for $E$. coli. The percentage of hybridized DNA was calculated as described by De Ley et al. (16). The equipment used in the reassociation experiments has been described previously (46).

Scanning electron microscopy. Halibut eggs from an egg batch in which about $99 \%$ of the egg epiflora consisted of Flexibacter sp. (measured as the number of colony-forming units on MBA) were examined by scanning electron microscopy. The eggs were washed in sterile filtered (pore size, $0.22 \mu \mathrm{m}$ ) seawater and fixed in formaldehyde-glutaraldehyde (final concentrations, 2.5 and $2.0 \%$ [vol/vol], respectively) in $0.05 \mathrm{M}$ cacodylate buffer ( $\mathrm{pH} 7.2)(20)$. The eggs were postfixed in $1 \%$ osmium tetroxide in cacodylate buffer, dehydrated in ethanol, critical-point dried, and coated with gold-palladium. A JEOL model JSM-6400 scanning electron microscope operated at $6 \mathrm{kV}$ was used to examine the specimens.

Transmission electron microscopy. Strain EKC001 axenic bacterial growth from a 4-day-old MBA culture $\left(15^{\circ} \mathrm{C}\right)$ was examined by transmission electron microscopy. A drop of particle-free (autoclaved and ultracentrifuged), distilled water was placed on the bacterial growth, and the preparation was carefully stirred with a sterile toothpick. Samples $(30 \mu \mathrm{l})$ of the resulting bacterial suspension were applied to carbonand Formvar-coated 400-mesh copper grids, and the bacteria were allowed to adhere for $5 \mathrm{~min}$ at room temperature. Superfluous liquid was gently removed by using a piece of filter paper. The grids were allowed to air dry before they were stained three times ( $30 \mathrm{~s}$ each) in a $1 \%$ uranyl acetate solution. Electron microscopy was performed at $80 \mathrm{kV}$ with a JEOL model $100 \mathrm{CX}$ electron microscope.

\section{RESULTS}

Phenotypic characteristics. The cells were long, slender rods $(0.4$ by 2 to $20 \mu \mathrm{m})$ with gliding motility. Occasionally, filaments that were 70 to $100 \mu \mathrm{m}$ long were formed. Colonies were light yellow and flat with irregular edges on CYTA. Typical spreading growth was not observed on CYTA. However, on solidified N source-containing media spreading growth was observed. On MBA, colonies were light brownish yellow, flattened, and elevated with regular edges. Because of a rapid decrease in viability, the Flexibacter sp. strains had to be subcultured every 5 to 7 days. Bacterial growth on agar plates exhibited a characteristic pattern, with lysis in the center and viable cells toward the edges of each colony. Transmission electron microscopy confirmed the nonflagellated morphology and also revealed the presence of bacteriophages.

The $\mathrm{KOH}$ test used to determine the production of flexirubin pigments was negative. No microcyst formation was observed, but spherical cells (diameter, 0.5 to $0.7 \mu \mathrm{m}$ ) were found in the late exponential phase of growth. No growth occurred under anaerobic conditions or on tryptic soy agar or thiosulfate-citrate-bile-sucrose agar. The bacteria were gram negative and Kovacs oxidase and catalase positive. No $\mathrm{pH}$ change was observed in the medium when the strains were tested for oxidative-fermentative metabolism of glucose. Acid was not produced from any of the carbohydrates tested. Arginine dihydrolase, lysine decarboxylase, and ornithine decarboxylase activities were not detected, the bacteria were not able to utilize citrate as a sole carbon source, and they did not produce indole from tryptophan. Additional biochemical and physiological characteristics are shown in Tables 1 and 2. The homogeneity of the Flexibacter sp. isolates is reflected in the fact that they responded identically in the tests which we performed.

API ZYM tests. The following substrates were hydrolyzed by all of the Flexibacter sp. strains which we tested: 2-naphthyl-phosphate (acid and alkaline phosphatase), 2-naphthylbutyrate, 2-naphthyl-caprylate, L-leucyl-2-naphthylamide, L-valyl-2-naphthylamide, and naphthol-AS-BI-phosphate. The strains did not hydrolyze 2-naphthyl-myristate, L-cystyl-2-naphthylamide, $N$-benzoyl-DL-arginine-2-naphthylamide, $N$-glutaryl-phenylalanine-2-naphthylamide, 6-Br-2-naphthyl- $\alpha$ $D$-galactopyranoside, 2-naphthyl- $\beta$-D-galactopyranoside, naphthol-AS-BI- $\beta D$-glucuronide, 2-naphthyl- $\alpha$-D-glucopyranoside, $6-B r-2-n a p h t h y l-\beta$-D-glucopyranoside, 1-naphthyl- $N$-acetyl- $\beta$ D-glucosaminide, 6-Br-2-naphthyl- $\alpha$-D-mannopyranoside, and 2 -naphthyl- $\alpha$-L-fucopyranoside. The Flexibacter sp. strains differed from $F$. maritimus with respect to hydrolysis of L-cystyl2-naphthylamide and $N$-benzoyl-DL-arginine-2-naphthylamide, which were hydrolyzed by $F$. maritimus but not by the Flexibacter sp. strains.

Sodium dodecyl sulfate-polyacrylamide gel electrophoresis. Silver staining of the polyacrylamide gels clearly revealed differences between the protein pattern of strain VKB004, which was isolated from tank water, and the protein patterns of the two isolates obtained from egg epiflora, strains EKC001 and EKD002 ${ }^{\mathrm{T}}$ (Fig. 1, lanes 5, 3, and 4, respectively). In both the high- and low-molecular-weight regions strain VKB004 produced prominent bands that were not present in the strain EKC001 and EKD002 ${ }^{\mathrm{T}}$ patterns. In contrast, strains EKCO01 and EKD002 ${ }^{\mathrm{T}}$ produced almost identical electrophoretic patterns in both high- and lowmolecular-weight regions. However, small differences between these two isolates were observed. The protein pattern of strain VKB004 was completely different from the patterns of the reference strains, $F$. maritimus NCMB 2153 and NCMB $2154^{\mathrm{T}}$ (lanes 5, 1, and 2, respectively). Only minor similarities between strain NCMB 2153 and strains EKC001 and $\mathrm{EKD} 002^{\mathrm{T}}$ were observed (lanes 1,3 , and 4 , respectively). In contrast to strain NCMB 2153, the protein pattern of strain NCMB $2154^{\mathrm{T}}$ was similar in some ways to the patterns of strains EKC001 and EKD002 ${ }^{\mathrm{T}}$. However, differences in the band patterns were observed both in the high-molecularweight region (approximately $70,86,60$, and $50 \mathrm{kDa}$, as determined by comparison with the migration of standard proteins) and in the low-molecular-weight region (approximately $32 \mathrm{kDa}$ ). Minor differences between strains EKC001 and EKD002 ${ }^{\mathrm{T}}$ were also observed, but these differences were much less than the differences between these isolates and strain NCMB $2154^{\mathrm{T}}$.

DNA base compositions. The DNA $T_{m}$ values (19) for strains EKC001, EKD002 ${ }^{\mathrm{T}}$, and VKB004 were 78.0, 77.8, and $78.5^{\circ} \mathrm{C}$, respectively, in $0.5 \times \mathrm{SSC}$. The $T_{m}$ values for strains NCMB 2153 and NCMB $2154^{\mathrm{T}}$ were 77.8 and $77.7^{\circ} \mathrm{C}$, respectively. The $\mathrm{G}+\mathrm{C}$ contents of strains EKC001, $\mathrm{EKD} 002^{\mathrm{T}}$, and $\mathrm{VKB} 004$ were $30.8,30.3$, and $32.0 \mathrm{~mol} \%$, 


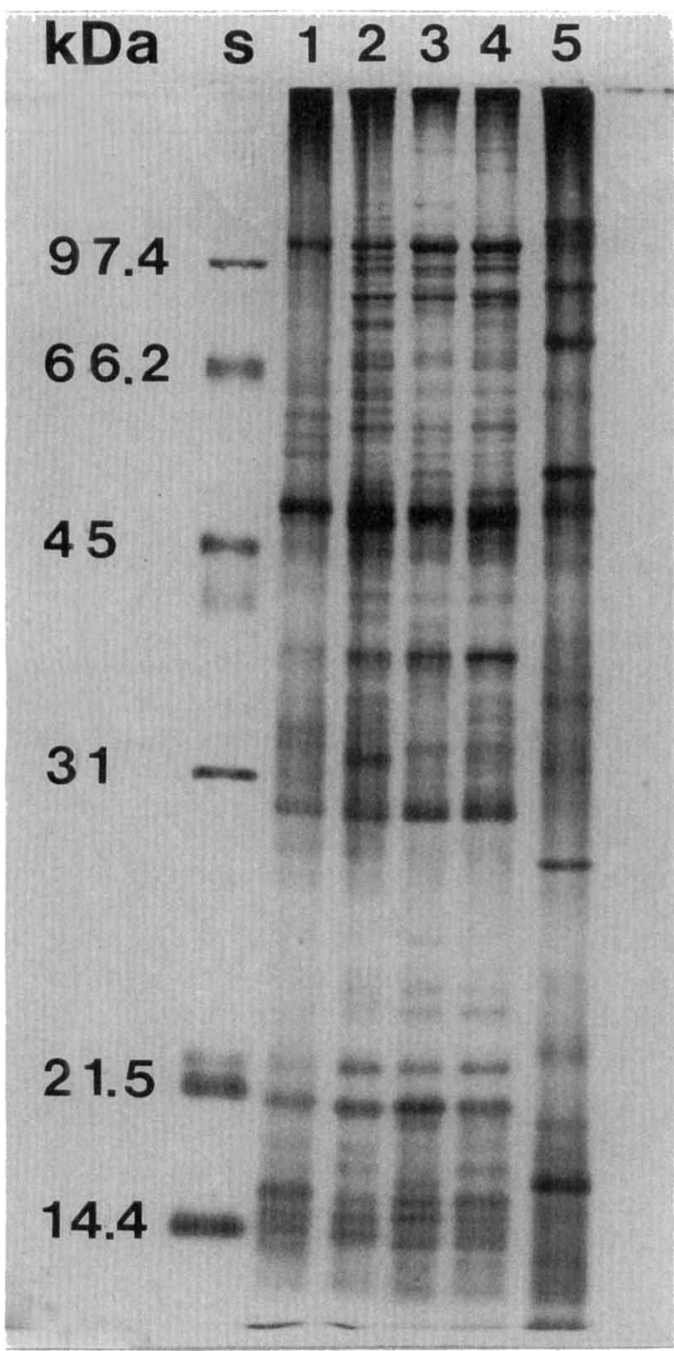

FIG. 1. Sodium dodecyl sulfate-polyacrylamide (12\%) gel electrophoresis of $F$. ovolyticus and $F$. maritimus. Lanes 1 and $2, F$. maritimus NCMB 2153 and NCMB $2154^{\mathrm{T}}$, respectively; lanes 3 through 5, F. ovolyticus EKC001, EKD002 ${ }^{\mathrm{T}}$ (from egg epiflora), and VKB004 (from tank water), respectively. Samples of $5 \mu 1$ per well were used. A $10-\mu l$ portion of a $100 \times$-diluted protein standard (low range; Bio-Rad) was also used (lane $\mathbf{S}$ ). The protein bands were visualized by silver staining.

respectively. The $\mathrm{G}+\mathrm{C}$ contents of $F$. maritimus NCMB $2154^{\mathrm{T}}$ and NCMB 2153 were 30.3 and $30.1 \mathrm{~mol} \%$, respectively. The values given by Wakabayashi et al. (48), who used calf thymus DNA ( $G+C$ content, $42.9 \mathrm{~mol} \%$ ) as a standard, were 31.6 mol\% for strain NCMB $2154^{\mathrm{T}}$ and 31.3 to $32.5 \mathrm{~mol} \%$ for $F$. maritimus.

DNA-DNA hybridization. The levels of DNA relatedness among Flexibacter sp. strains EKC001, EKD002 ${ }^{\mathrm{T}}$, and VKB004 and $F$. maritimus NCMB $2154^{\mathrm{T}}$ and NCMB 2153 are shown in Table 4. The DNA-DNA hybridization experiments revealed high levels of homology among the three strains of Flexibacter sp., but strain VKB004 differed slightly from strains EKCO01 and EKD002 ${ }^{\mathrm{T}}$. Our results clearly separated the Flexibacter sp. strains from $F$. maritimus and demonstrated the relatedness of the three Flexibac$t e r$ sp. strains. The reassociation value for $F$. maritimus was somewhat higher than the value of $73 \%$ reported by Bernar- det and Grimont (9), which may have been in part due to differences in methodological approaches.

Flexibacter-infected halibut eggs. The new Flexibacter species was isolated as part of the adherent bacterial epiflora of eggs obtained from different egg batches; the percentage of this organism in the epiflora ranged from a few percent to $99 \%$. When the bacterium formed less than 25 to $30 \%$ of the epiflora, the eggs hatched and developed normally, while eggs on which Flexibacter sp. constituted the major part of the bacterial epiflora exhibited a dramatic increase in the level of mortality at the hatching stage. In the latter cases, Flexibacter sp. accounted for as much as 60 to $70 \%$ of the colony-forming units in water samples obtained from the egg and larval incubators, while in the former cases, Flexibacter sp. was scarcely detectable when the viable count method was used. These results emphasize the opportunistic nature of Flexibacter sp. with respect to disease in halibut larvae.

Scanning electron microscopy of infected halibut eggs revealed that a very high level of proteolytic activity was caused by the Flexibacter sp. strains. Colonization resulted in wounds or ulcerations of varying severity on otherwise clean egg surfaces (Fig. 2). The chorion (the outermost layer of the egg shell) was completely dissolved, and the underlying zona radiata was severely damaged by bacterial exoenzymatic activity, possibly resulting in egg puncture, leakage of cell constituents, and larval death (5).

\section{DISCUSSION}

Various Flexibacter spp. are known to cause diseases in different fish species $(1,7,8,23,47)$. The Flexibacter sp. which we studied is an opportunistic pathogen that causes high levels of mortality in halibut eggs and larvae when it is present in high numbers or when larval resistance is weakened because of different environmental stresses (37). This is a common characteristic of many of the fish-pathogenic bacteria $(10,13,14,18,42)$. Scanning electron microscopy of infected halibut eggs revealed that our Flexibacter sp. had the enzymatic capacity to dissolve both the chorion and the zona radiata of egg shells (Fig. 2). As far as we know, this characteristic has not been reported for any of the previously described fish-pathogenic bacteria, although bacteria that dissolve the chorion of cod (Gadus morhua L.) eggs have been observed (21). It is likely that exoenzymatic bacterial activity is the cause of the characteristic mortality pattern observed in infected eggs.

All of our Flexibacter sp. strains exhibited a growth pattern that was characterized by a rapid decrease in viability after 5 to 7 days both in liquid media and on solid media. This might have been the result of lysogenic induction of temperate phages by some unknown factor because we detected bacteriophages in all of the strains. The factors responsible for the lysogenic induction are unknown, and we were not able to cure any of the strains of their phages. Recent studies have shown that bacteriophages are abundant in natural aquatic environments and are closely coupled to microbial trophodynamics $(3,11,39)$. Thus, it is possible that bacteriophages are involved in the rapid decrease in viability that is often encountered during primary isolation of bacterial populations from various environmental sources (e.g., soil and seawater).

The strains which we isolated form a very homogeneous group, and they responded identically to morphological and biochemical tests. Bernardet and Grimont (9) included $C y$ tophaga psychrophilus and Cytophaga columnaris in the genus Flexibacter, mainly on the basis of the inability of 
TABLE 4. Levels of DNA relatedness for $F$. ovolyticus EKC001, EKD002 ${ }^{\mathrm{T}}$, and VKB004 and $F$. maritimus NCMB $2154^{\mathrm{T}}$ and NCMB 2153

\begin{tabular}{|c|c|c|c|c|c|}
\hline \multirow{2}{*}{$\begin{array}{l}\text { Strain used as } \\
\text { recipient DNA }\end{array}$} & \multicolumn{5}{|c|}{ \% Relatedness with donor DNA prepared from: } \\
\hline & $\begin{array}{c}\text { Strain } \\
\text { EKC001 }\end{array}$ & $\begin{array}{c}\text { Strain } \\
\text { EKD002 }^{\mathrm{T}}\end{array}$ & $\begin{array}{c}\text { Strain } \\
\text { VKB004 }\end{array}$ & $\begin{array}{c}\text { Strain } \\
\text { NCMB 2154 }\end{array}$ & $\begin{array}{c}\text { Strain } \\
\text { NCMB 2153 }\end{array}$ \\
\hline EKC001 & $100^{a}$ & & & & \\
\hline $\mathrm{EKD} 02^{\mathrm{T}}$ & 96.7 & 100 & & & \\
\hline VKB004 & 92.7 & 91.5 & 100 & & \\
\hline NCMB $2154^{T}$ & 42.9 & 42.7 & 40.4 & 100 & \\
\hline NCMB 2153 & 30.3 & 30.0 & 26.4 & 85.6 & 100 \\
\hline
\end{tabular}

a The levels of hybridized DNA are expressed as percentages that are based on spectrophotometrically determined initial renaturation rates. The levels of renaturation for homologous DNAs were normalized to $100 \%$.

these organisms to degrade polysaccharides. Much work will need to be done to develop a proper taxonomy for the Cytophaga-Flexibacter-Flavobacterium phylogenetic branch. Taking into account the current state of knowledge, we agree with Bernardet and Grimont that polysaccharide degradation should be emphasized and propose that the strains which we isolated belong to the genus Flexibacter. The name Flexibacter maritimus (= Cytophaga marina in Bergey's Manual of Systematic Bacteriology [40]) has been validly published previously $(24,48)$. Thus, fish-pathogenic, gliding bacteria from both marine and freshwater environments have been placed in the genus Flexibacter. These organisms have DNA $\mathrm{G}+\mathrm{C}$ contents ranging from 30 to $34 \mathrm{~mol} \%$ and do not have the capacity to degrade polysaccharides. On the basis of their low $\mathrm{G}+\mathrm{C}$ contents, their resemblance in phenotypic characteristics to $F$. maritimus, and the descriptions of Bernardet and Grimont of $F$. columnaris and $F$. psychro- philus, we propose that our egg-damaging strains should be named Flexibacter ovolyticus sp. nov.

That this decision is appropriate is shown by the DNADNA hybridization results, which revealed close relationships among the three $F$. ovolyticus strains examined (91.5 to 96.7\%) (Table 4). Levels of relatedness of 40.4 to 42.9 and 26.4 to $30.3 \%$ between $F$. ovolyticus and $F$. maritimus NCMB $2154^{\mathrm{T}}$ and NCMB 2153 , respectively, qualify these organisms for positions in different species (28). The differences in sodium dodecyl sulfate-polyacrylamide gel electrophoresis patterns between the two egg isolates (strains EKC001 and $E K D 002^{\mathrm{T}}$ ) and the water isolate (strain VKB004) (Fig. 1) may reflect differences in protein expression. The divergent characteristics of strain VKB004 are underlined by its somewhat higher $\mathrm{G}+\mathrm{C}$ content (Table 1) and its levels of DNA relatedness (about 90\%) with strains EKC001 and EKD002 ${ }^{\mathrm{T}}$, which were related to each other at

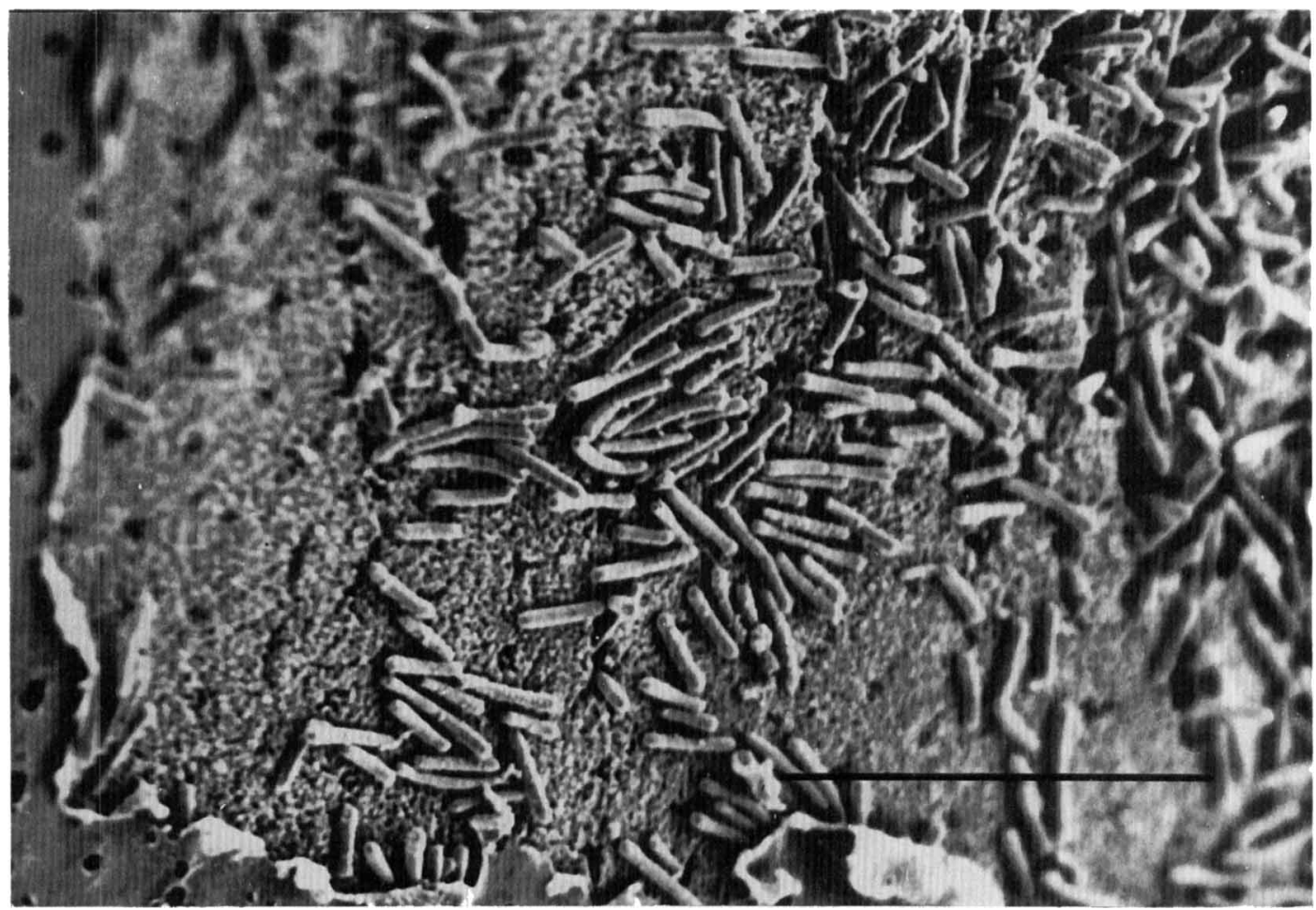

FIG. 2. Scanning electron microscopy of the surface of a $F$. ovolyticus-infected halibut egg. The chorion was dissolved by bacterial exoenzymatic activity, and the bacteria attacked the underlying zona radiata. The micrograph shows the edge of a wound, with undamaged egg surface to the left and severe attack on the zona radiata to the right. Bar $=10 \mu \mathrm{m}$. 
a level of about $97 \%$ (Table 4). Characteristics that differentiate $F$. ovolyticus from previously described Cytophaga and Flexibacter species that have $\mathrm{G}+\mathrm{C}$ contents between 30 and $36 \mathrm{~mol} \%$ are shown in Table 3.

Description of Flexibacter ovolyticus sp. nov. Flexibacter ovolyticus (ō'vō.lyt.ic'us. L.n. ovum, egg, Gr.n. hysis, loosening or dissolution; ovolyticus, egg damaging). The cells are gram-negative, long, slender rods $(0.4$ by 2 to $20 \mu \mathrm{m})$ which occasionally grow to filaments that are 70 to $100 \mu \mathrm{m}$ long. Colonies are Kovacs oxidase positive and pale yellow. Microcysts are not formed. The cells exhibit gliding motility, do not adsorb Congo red, and do not possess a flexirubin type of pigment. $F$. ovolyticus is strictly aerobic and does not produce acid from carbohydrates. It degrades gelatin, tyrosine, DNA, and Tween 80 , but starch, cellulose, and chitin are not degraded. $F$. ovolyticus possesses catalase and nitrate reductase activities. $\mathrm{H}_{2} \mathrm{~S}$ is not produced, and $50 \%$ seawater is required for growth. Alternatively, media based on artificial seawater containing at least $1 \% \mathrm{NaCl}$ may be used. $F$. ovolyticus grows at $4^{\circ} \mathrm{C}$, but not at $30^{\circ} \mathrm{C}$. The $\mathrm{G}+\mathrm{C}$ contents of the DNAs of strains EKC001, EKD002 ${ }^{\mathrm{T}}$, and VKB004 range from 30.3 to $32.0 \mathrm{~mol} \%$. Additional characteristics of $F$. ovolyticus are shown in Tables 1,2 , and 4.

Type strain EKD002 (= NCIMB 13127) was isolated in 1989 from the adherent epiflora of halibut eggs at the Austevoll Aquaculture Research Station in western Norway. The description of the type strain corresponds to the species description. The $\mathrm{G}+\mathrm{C}$ content of the DNA of the type strain is $30.3 \mathrm{~mol} \%$. In addition to the type strain, strains EKC001 and VKB004 have been deposited in the National Collection of Industrial and Marine Bacteria as strains NCIMB 13128 and NCIMB 13129, respectively.

\section{ACKNOWLEDGMENTS}

We thank M.-A. Sæle, E. Digranes, and S. Næss for excellent technical assistance and $\mathrm{H}$. Wakabayashi for kindly providing strains equivalent to $F$. maritimus NCMB $2154^{\mathrm{T}}$ and NCMB 2153. The Electron Microscopic Laboratory of the Faculty of Science, University of Bergen, is acknowledged for assistance with the electron microscopy and photographic work. We also thank J. A. Olafsen, I. Dundas, B. T. Lunestad, J. Goks $\emptyset$ yr, and $\emptyset$. Enger for discussions and valuable comments on the manuscript.

Financial support from the Norwegian Fisheries Research Council (grant V 101.017) and the Royal Norwegian Council for Scientific and Industrial Research (grant 10.12.221325) is gratefully acknowledged.

\section{REFERENCES}

1. Amend, D. F. 1983. Columnaris (Flexibacter columnaris) disease of freshwater fishes and a brief review of other flexibacterial diseases of fish, p. 139-151. In D. P. Anderson, M. Dorson, and P. Dubourget (ed.), Antigens of fish pathogens. Symposium International de Talloires. Collection Foundation Marcel Mérieux, Lyon, France.

2. Anacker, R. L., and E. J. Ordal. 1959. Studies on the myxobacterium Chondrococcus columnaris. I. Serological typing. J. Bacteriol. 78:25-32.

3. Bergh, Ø., K. Y. Børsheim, G. Bratbak, and M. Heldal. 1989. High abundance of viruses found in aquatic environments. Nature (London) 340:467-468.

4. Bergh, Ø., G. H. Hansen, and A. Jelmert. 1990. Bacterial diseases of eggs and yolk sac larvae of halibut (Hippoglossus hippoglossus L.): characterization and experimental infection, report no. F:38. Counc. Meet., Int. Counc. Explor. Sea 1990.

5. Bergh, Ø., G. H. Hansen, and R. E. Taxt. Experimental infection of eggs and yolk sac larvae of halibut (Hippoglossus hippoglossus L.). J. Fish Dis., in press.
6. Bergh, $\emptyset$., and A. Jelmert. Submitted for publication.

7. Bernardet, J. F. 1989. "Flexibacter columnaris": first description in France and comparison with bacterial strains of other origins. Dis. Aquat. Org. 6:37-44.

8. Bernardet, J. F., A. C. Campbell, and J. A. Buswell. 1990. Flexibacter maritimus is the agent of "black patch necrosis" in Dover sole in Scotland. Dis. Aquat. Org. 8:233-237.

9. Bernardet, J. F., and P. A. D. Grimont. 1989. Deoxyribonucleic acid relatedness and phenotypic characterization of Flexibacter columnaris sp. nov., nom. rev., Flexibacter psychrophilus sp. nov., nom. rev., and Flexibacter maritimus Wakabayashi, Hikida, and Masumura 1986. Int. J. Syst. Bacteriol. 39:346-354.

10. Bolinches, J., and E. Egidius. 1987. Heterotrophic bacterial communities associated with the rearing of halibut Hippoglossus hippoglossus with special reference to Vibrio spp. J. Appl. Ichthyol. 3:165-173.

11. Bratbak, G., M. Heldal, S. Norland, and T. F. Thingstad. 1990. Viruses as partners in spring bloom microbial trophodynamics. Appl. Environ. Microbiol. 56:1400-1405.

12. Buck, J. D. 1982. Nonstaining (KOH) method for determination of Gram reactions of marine bacteria. Appl. Environ. Microbiol. 44:992-993.

13. Colorni, A., I. Paperna, and H. Gordin. 1981. Bacterial infections in gilt-head sea bream Sparus aurata cultured at Elat. Aquaculture 23:257-267.

14. Colwell, R. R., and D. J. Grimes. 1984. Vibrio diseases of marine fish populations. Helgol. Meeresunters. 37:265-287.

15. De Ley, J. 1970. Reexamination of the association between melting point, buoyant density, and chemical base composition of deoxyribonucleic acid. J. Bacteriol. 101:738-754.

16. De Ley, J., H. Cattoir, and A. Reynaerts. 1970. The quantitative measurement of DNA hybridization from renaturation rates. Eur. J. Biochem. 12:133-142.

17. Dworkin, M., and S. M. Gibson. 1964. A system for studying microbial morphogenesis: rapid formation of microcysts on Myxococcus xanthus. Science 146:243-244.

18. Egidius, E. 1987. Vibriosis: pathogenicity and pathology. A review. Aquaculture 67:15-28.

19. Gillis, M., J. De Ley, and M. De Cleene. 1970. The determination of molecular weight of bacterial genome DNA from renaturation rates. Eur. J. Biochem. 12:143-153.

20. Glauert, A. M. 1975. Practical methods in electron microscopy, vol. 3. Elsevier/North-Holland Publishing Co., Amsterdam.

21. Hansen, G. H., and J. A. Olafsen. 1989. Bacterial colonization of cod (Gadus morhua L.) and halibut (Hippoglossus hippoglossus) eggs in marine aquaculture. Appl. Environ. Microbiol. 55:1435-1446.

22. Hansen, G. H., and R. Sørheim. 1991. Improved method for phenotypical characterization of marine bacteria. J. Microbiol. Methods 13:231-241.

23. Hilger, I., S. Ullrich, and K. Anders. 1991. A new ulcerative flexibacteriosis-like disease ("yellow pest") affecting young Atlantic cod Gadus morhua from the German Wadden Sea. Dis. Aquat. Org. 11:19-29.

24. International Committee on Systematic Bacteriology Subcommittee on the Taxonomy of Flavobacterium- and Cytophaga-like Bacteria. 1991. Minutes of the meetings. Int. J. Syst. Bacteriol. 41:460-461.

25. Johnson, J. L., and W. S. Chilton. 1966. Galactosamine glycan of Chondrococcus columnaris. Science 152:1247-1248.

26. Jooste, P. J., T. J. Britz, and J. DeHaast. 1985. A numerical taxonomic study of Flavobacterium-Cytophaga strains from diary sources. J. Appl. Bacteriol. 59:311-323.

27. Kent, M. L., J. M. Groff, J. K. Morrison, W. T. Yasutake, and R. A. Holt. 1989. Spiral swimming behavior due to cranial and vertebral lesions associated with Cytophaga psychrophila infections in salmonid fishes. Dis. Aquat. Org. 6:11-16.

28. Krieg, N. R., and J. G. Holt (ed.). 1984. Bergey's manual of systematic bacteriology, vol. 1. The Williams \& Wilkins Co., Baltimore.

29. Laemmli, U. K. 1970. Cleavage of structural proteins during the assembly of the head of bacteriophage T4. Nature (London) 277:680-685. 
30. Lewin, R. A., and D. M. Lounsbery. 1969. Isolation, cultivation and characterization of flexibacteria. J. Gen. Microbiol. 58:145170.

31. Mandel, M., and J. Marmur. 1968. Use of ultraviolet absorbance-temperature profile for determining the guanine plus cytosine content of DNA. Methods Enzymol. 12B:195-206.

32. Marmur, J. 1963. A procedure for the isolation of deoxyribonucleic acid from microorganisms. Methods Enzymol. 6:726738.

33. Marshall, T., and A. L. Latner. 1981. Incorporation of methylamine in an ultrasensitive silver stain for detecting protein in thick polyacrylamide gels. Electrophoresis 2:228-235.

34. Masumura, K., and H. Wakabayashi. 1977. An outbreak of gliding bacterial disease in hatchery-born red seabream (Pagrus major) and gilthead (Acanthopagrus schlegeli) fry in Hiroshima. Fish Pathol. 12:171-177.

35. Mudarris, M., and B. Austin. 1989. Systemic disease in turbot Scophthalmus maximus by a previously unrecognised Cytophaga-like bacterium. Dis. Aquat. Org. 6:161-166.

36. Oppenheimer, C. H. 1955. The effect of marine bacteria on the development and hatching of pelagic fish eggs and the control of such bacteria by antibiotics. Copeia 1:43-49.

37. Pittman, K., Ø. Bergh, I. Opstad, A. B. Skiftesvik, L. Skjolddal, and H. Strand. 1990. Development of eggs and yolk sac larvae of halibut (Hippoglossus hippoglossus L.). J. Appl. Ichthyol. 6:142-160.

38. Pittman, K., A. B. Skiftesvik, and L. Berg. 1990. Morphological and behavioural development of halibut, Hippoglossus hippoglossus (L.) larvae. J. Fish Biol. 37:455-472.

39. Proctor, L. M., and J. A. Fuhrman. 1990. Viral mortality of marine bacteria and cyanobacteria. Nature (London) 343:60-62.

40. Reichenbach, H. 1989. Family I. Cytophagaceae Stanier 1940 630 AL emend., p. 2013-2050. In J. T. Staley, M. P. Bryant, N. Pfennig, and J. G. Holt (ed.), Bergey's manual of systematic bacteriology, vol. 3. The Williams \& Wilkins Co., Baltimore.

41. Reichenbach, H., and O. B. Weeks (ed.). 1981. The Flavobacterium-Cytophaga group, p. 1-217. Verlag Chemie, Weinheim, Germany.

42. Rødsæther, M. C., J. A. Olafsen, J. Raa, K. Myhre, and J. B. Steen. 1977. Copper as an initiating factor of vibriosis (Vibrio anguillarum) in eel (Anguilla anguilla). J. Fish Biol. 10:17-21.

43. Shelbourne, J. E. 1963. A marine fish-rearing experiment using antibiotics. Nature (London) 198:74-75.

44. Soriano, S. 1973. Flexibacteria. Annu. Rev. Microbiol. 27:155170 .

45. Tilseth, S. 1990. New marine fish species for cold-water farming. Aquaculture 85:235-245.

46. Torsvik, V. L., J. Goksøyr, and F. L. Daae. 1990. High diversity in DNA of soil bacteria. Appl. Environ. Microbiol. 56:782-787.

47. Wakabayashi, H., M. Hikida, and K. Masumura. 1984. Flexibacter infection in cultured marine fish in Japan. Helgol. Meeresunters. 37:587-593.

48. Wakabayashi, H., M. Hikida, and K. Masumura. 1986. Flexibacter maritimus sp. nov., a pathogen of marine fishes. Int. J. Syst. Bacteriol. 36:396-398.

49. Wiik, R., V. Torsvik, and E. Egidius. 1986. Phenotypic and genotypic comparisons among strains of the lobster pathogen Aerococcus viridans and other marine Aerococcus viridans-like cocci. Int. J. Syst. Bacteriol. 36:431-434. 